\title{
Environmental changes during the Late Ordovician-early Silurian linked to volcanism
}

\author{
YANFANG Li ${ }^{1}$, TONGWEI ZHANG ${ }^{2}$, BAOJIAN SHEN ${ }^{1}$
}

${ }^{1}$ Wuxi Researc Institute of Petroleum Geology, SINOPEC Petroleum Exploration and Production Research Institute, Wuxi, Jiangsu 214126, China

E-mail address: liyf_2017.syky.sinopec.com (Y. Li)

${ }^{2}$ Bureau of Economic Geology, The University of Texas at Austin, TX 78713, United States

The Late Ordovician to early Silurian was a time of dramatic climatic and environmental changes that may have resulted in mass extinction. Intense volcanisms have been proposed as a trigger for these changes, but their causal relationships remain controversial. Here we present trace element contents, organic carbon and pyrite sulfur isotopes $\left(\delta^{13} \mathrm{C}_{\text {org }}, \delta^{34} \mathrm{~S}_{\mathrm{pyr}}\right.$ ), and mercury ( $\left.\mathrm{Hg}\right)$ concentrations from two Ordovician-Silurian sections in South China in order to better understand environmental changes and their potential relationships to volcanism. Our new data show that the concurrent positive excursions in $\delta^{34} \mathrm{~S}_{\text {pyr }}$ and $\delta^{13} \mathrm{C}_{\text {org }}$ occurred during the Hirnantian and Aeronian stage. The positive excursions in $\delta^{34} \mathrm{~S}_{\mathrm{pyr}}$ and $\delta^{13} \mathrm{C}_{\text {org }}$ were associated with the decreased TOC value and relatively less reducing condition, so they were not the indicative of expansion of anoxic condition, in contrast to previous claims. The Katian and Rhuddanian strata were characterized by the negative excursions in $\delta^{34} \mathrm{~S}_{\text {pyr }}$ and $\delta^{13} \mathrm{C}_{\text {org }}$. The two negative isotopic shifts coincide with increased TOC value, euxinic condition, and extremely high $\mathrm{Hg}$ concentrations. Thus, we proposed that the negative excursions in $\delta^{34} \mathrm{~S}_{\mathrm{pyr}}$ and $\delta^{13} \mathrm{C}_{\mathrm{org}}$ were caused by volcanic activity via emitting $\mathrm{CO}_{2}$ and $\mathrm{SO}_{2}$. The cessation of volcanic activity and co-burial of pyrite and organic carbon were responsible for the positive excursions in $\delta^{34} S_{\text {pyr }}$ and $\delta^{13} \mathrm{C}_{\text {org. }}$. These observations demonstrated that volcanism played a major role in triggering environmental changes during Late Ordovician to early Silurian. 